Volume 4 No.1 September 2018

p-ISSN : 2460-8750 e-ISSN : 2615-1731

http://dx.doi.org/ 10.26858/talenta.v4i1.6784

\title{
PENERAPAN MODEL PEMBELAJARAN SENTRA DALAM PENGEMBANGAN KECERDASAN BAHASA EKSPRESIF ANAK USIA DINI \\ ${ }^{1,2}$ Farny Sutriany Jafar ${ }^{1}$, Malpaleni Satriana ${ }^{2}$ \\ Fakultas KeguruanIlmu Pendidikan,Universitas Mulawarman. Indonesia Email: farny_sutriany@yahoo.co.id malpa.mz@gmail.com $^{2}$
}

(c) (8) 18 -JPT Fakultas Psikologi Universitas Negeri Makassar. Ini adalah artikel dengan akses terbuka dibawah licenci CC BY-NC-4.0

(https://creativecommons.org/licenses/by-nc/4.0/ ).

\begin{abstract}
Abstrack. This study aims to describe: (1) implementation of a learning model center in the development of expressive language of early childhood, and (2) The factors that influence the development of early childhood expressive language in the center learning model. The method used is qualitative research with a case study approach. Data collection techniques were carried out using: (1) Field observations to observe all activities carried out in TK Negeri 01 Tenggarong, (2) Methods of interviews conducted by teachers, students and principals of TK Negeri 01 Tenggarong, (3) Method of documentation, as supporting to obtain data in the field, and from the documentation / recording results are transcribed and grouped and then analyzed using a flow model, which starts with (a) data reduction, (b) data presentation, (c) conclusions. The results showed that: (1) the center learning model was instrumental in developing children's expressive language intelligence, because children can learn to communicate with other people in various ways, children are also able to express feelings, ideas with appropriate word choices when communicating (2) factors that influence the development of expressive language of early childhood in the center learning model are: health factors, intelligence factors, family socioeconomic status, gender, and family relationships.
\end{abstract}

Keywords: learning center, expressive language, early childhood.

\begin{abstract}
Abstrak. Penelitian ini bertujuan untuk mendiskrpsikan : (1) pelaksanaan model pembelajaran sentra dalam pengembangan bahasa ekspresif anak usia dan (2) faktor yang mempengaruhi pengembangan bahasa ekspresif anak usia dini dalam model pembelajaran sentra. Metode yang digunakan adalah penelitian kualitatif dengan pendekatan studi kasus. Teknik pengumpulan data data dilakukan dengan mengunakan : (1) Observasi lapangan untuk mengamati semua kegiatan yang dilakukan di TK Negeri 01 Tenggarong, (2) Metode wawancara yang dilakukan guru, murid dan kepala sekolah TK Negeri 01 Tenggarong, (3) Metode dokumentasi, sebagai penunjang untuk memperoleh data di lapangan, dan dari hasil dokumentasi/perekaman di transkipkan dan dikelompokkan kemudian di analisis mengunakan model alir, yang dimulai dengan (a) reduksi data, (b) penyajian data, (c) penarikan kesimpulan. Hasil penelitian menunjukkan bahwa: (1) model pembelajaran sentra sangat berperan dalam mengembangkan kecerdasan bahasa ekspresif anak, karena anak-anak dapat belajar berkomunikasi dengan orang lain berbagai cara, anak juga mampu mengungkapkan perasaan, ide dengan pilihan kata yang sesuai ketika berkomunikasi (2) faktor yang mempengaruhi pengembangan bahasa ekspresif anak usia dini dalam model pembelajaran sentra adalah : faktor kesehatan, faktor intelegensi, status sosial ekonomi keluarga, jenis kelamin, dan hubungan keluarga.
\end{abstract}

Kata Kunci: pembelajaran sentra, bahasa ekspresif, anak usia dini 


\section{PENDAHULUAN}

Perkembangan bahasa merupakan salah satu aspek yang perlu dikembangkan bagi anak usia dini, karena perkembangan bahasa adalah sarana anak untuk berkomunikasi dengan teman orang tua, guru, dan teman sebaya.Perkembangan bahasa mengikuti suatu urutan yang dapat diramalkan secara umum sekalipun terdapat vareasi diantara anak satu dengan lainnya, dengan tujuan untuk mengembangkan kemampuan anak berkomunikasi.

Kebanyakan anak memulai perkembangan bahasanya dari menangis untuk mdngekspresikan responnya terhadap bermacam-macam stimulan. Ssetelah itu anak mulai memeram yaitu melafalkan bunyi yang tidak ada artinya secara berulang. Setelah itu anak mulai belajar kalimat dengan satu kata, seperti "maem" yang artinya minta makan. Anak pada umumnya belajar naka-nama benda sebelum kata-kata yang lain.brewer mengklasifikasikan bahasa anak sebagaireferensial dan ekspresif. Katakata benda pada umumnya digolongkan dalam referensial, sdangkan kata-kata sossial di golongkan sebagai ekspresif. Perkembangan bahasa belum sempurna sampai akhir masa bayi, dan akan terusberkembangang sepanjang kehidupan seseorang. Anak terus membuat perolehan kosa kata baru, dan anak usia 3-4 tahun mulai belajar menyusun kalimat Tanya dan kalimat negative.
Perkembangan bahasa bertujuan untuk mengembangkkan kemampuan anak atau seseorang untuk berkomunikasi. Pada anak berusia 3-4 tahun mulai belajar menyusun kalimat tanya dan kalimat negatif. Pada usia 5 tahun mereka telah menghimpun kuranglebih 8.000 kosa kata, disamping itu telah menguasai hampir semua bentuk dasar tata bahasa. Melalui pengembangan bahasa, setiap manusia dapat mengenal dirinya, sesamanya, alam sekitar, ilmu pengetahuan, dan nilai-nilai moral atau agama.

Masa perkembangan bahasa pada anak usia dini tidak bisa terlepas dari orang tua, karena Karena proses awal mulanya bahasa pada anak itu sendiri dari hasil mencontoh orang dewasa yakni orang tuanya. Oleh karena itu orang tua harus mampu memberikan contoh yang baik dalam hal berkomunikasi. Untuk menunjang bahasa anak orang tua dapat melakukan kegiatan - kegiatan dengan anak misalnya melakukan kegiatan bercakapcakap bercerita dan menjawab pertanyaan.

Perkembangan anak usia dini yang sangat pesat, maka perlu ada perubahan model pembelajaran di TK untuk mendukung perkembangan anak. Pembelajaran di Indonesia harus sesuai dengan tumbuh kembang anak mulai dari kelompok bermain, dan taman kanak-kanak yaitu dengan bermain. Pembelajaran dengan bermain dapat dilaksanakan dengan model pembelajaran sentra. 
Sentra adalah area yang dirancang dengan baik, yang intinya merencanakan pembelajaran yang aktif dan bahannya diambil dari kurikulum program kemampuan dasar dan tema yang sudah diajarkan. Hal penting dalam pelaksanaan model pembelajaran sentra, yaitu: intensitas bermain dan densitas bermain. Intensitas bermain adalah waktu yang dibutuhkan untuk pengalaman anak dalam 3 jenis main disepanjang hari dan sepanjang tahun, sedangkan densitas bermain adalah berbagai cara bermain pada setiap jenis main yang disediakan untuk mendukung pengalaman anak.

Masalah yang sering di alami oleh anak adalah kebanyakan dari mereka belum memahami cara mengekspresikan kebutuhan, keinginan dan perasaan secara verbal. Terkadang anak belum bisa berbicara lebih jelas dan tegas sehingga tidak mudah dipahami. Pada pembelajaran semester 2 telah dikenalkan cara pembelajaran untuk anak bisa berbahasa ekspresif atau anak mampu mengungkapkan keinginan dan perasaannya secara verbal. Ternyata sebagian besar anak kelompok B di Taman kanak-kanak Negeri 01 yang berjumlah 11 anak, masih ada 5 anak sulit untuk mengungkapkan perasaannya atau berbahasa ekspresif nya masih kurang.

Hasil dari penerapan pembelajaran sentra dapat mengembangkan bahasa ekspresif anak usia. Anak bisa merumuskan konsep atau kosakata sesuai tema untuk memperluas bahasa anak, anak juga bisa berbicara dengan bahasa positif kepada orang dewasa.

Berdasarkan konteks penelitian tersebut, maka fokus penelitian ini adalah "penerapan model pembelajaran sentra dalam pengembangan kecerdasan bahasa ekspresif anak usia dini pada kelompok B di Tk Negeri 01 tenggarong”, selanjutnya subfokus penelitian dari penelitian ini adalah “1) pelaksanaan model pembelajaran sentra dalam pengembangan bahasa ekspresif anak usia dini pada kelompok B di TK Negeri 01 Tenggarong, 2) Faktor yang mempengaruhi pengembangan bahasa ekspresif anak usia dini dalam model pembelajaran sentra di TK Negeri 01 Tenggarong”.

\section{METODE}

Pendekatan yang digunakan adalah pendekatan kualitatif. Jenis penelitian yang digunakan dalam penelitian ini yaitu jenis penelitian studi kasus. Studi kasus merupakan jenis penelitian yang mendalam tentang individu, kelompok, institusi, dan sebagainya dalam waktu tertentu. Tujuan studi kasus adalah berusaha menemukan makna, menyelidiki proses, serta memperoleh pengertian dan pemahaman yang mendalam serta untuh dari individu, kelompok, atau situasi tertentu. Data studi kasus diperoleh dengan wawancara, 
observasi, dan mempelajari berbagai dokumen yang terkait dengan topik yang diteliti (Sugiarto, 2015:12).

Penelitian ini akan dilaksanakan di TK Negeri 01 yang terletak jalan Tiung No 01 RT IX Kelurahan Sukarame, Kecamatan Tenggarong.

Teknik pengumpulan data dapat dilakukan dengan cara observasi (pengamatan) pada guru, anak serta proses pembelajaran, interview (Wawancara) kepada guru dan kepala sekolah, dan dokumentasi atau studi dokumen lainnya.

Dari hasil berbagai sumber seperti penelitian yang relevan diantaranya, dilakukan oleh Arifa dalam penelitiannya yang berjudul Peningkatan Keterampilan Bercerita Ekspresif Anak Usia 5-6 Tahun Dengan Role Playing Di Tk Arum Puspita Triharjo Pandak Bantul. Pudjaningsih Metode Pengembangan Bahasa: Penerapannya Pada Pembelajaran Berbasis Tema Dan Sentra Di Taman Kanak-Kanak. Serta dari pengamatan atau observasi, catatan lapangan, wawancara dan dokumentasi/perekaman di transkipkan dan dikelompokkan kemudian di analisis mengunakan model alir, yang dimulai dengan (a) reduksi data, (b) penyajian data, (c) penarikan kesimpulan.

\section{HASIL DAN PEMBAHASAN}

\section{Pelaksanaan Model Pembelajaran} Sentra dalam Pengembangan

\section{Kecerdasan Bahasa Ekspresif anak usia dini di TK Negeri 01Tenggarong}

Model pembalajaran sentra sendiri adalah model pembelajaran yang menitik beratkan sentra bermain pada saat pembelajaran. Sentra bermain merupakan area kegiatan yang dirancang di dalam atau di luar kelas, berisi berbagai kegiatan bermain dengan bahan-bahan yang dibutuhkan dan disusun berdasarkan kemampuan anak serta sesuai dengan tema yang dikembangkan dan dirancang terlebih dahulu.

Sentra memungkinkan anak untuk melakukan manipulasi terhadap berbagai obyek, terlibat dalam role playing saling bercakap-cakap dengan teman-temannya, bereksplorasi, berinteraksi secara fisik, emosional, sosial dan secara kognitif serta kegiatan variatif yang menarik lainnya. Sentra memberikan kesempatan pada anak untuk bermain baik secara individual, kelompok kecil maupun kelompok besar dan bahkan secara klasikal. Anak diperbolehka nmemilih kegiatan yang menarik baginya dan akhirnya akan menjadikan anak sebagai pembelajar yang aktif dan interaktif.

Kegiatan bermain dilakukan anak dalam kelompok kecil di sentra atau area yang di dalamnya terdapat berbagai material bermain. Setiap sentra bermain telah 
disiapkan oleh guru sesuai dengan Tercatat ada beberapa anak yang program pengembangan yang akan memperlihatkan peningkatan pengembangan diajarkan kepada anak dengan jadwal bahasa ekspresif khususnya pada indicator yang telah ditentukan. Semua kegiatan sebagai berikut:

bermain diarahkan untuk mencapai target yang disesuaikan dengan

a) Mengungkapkan keinginan, perasaan, dan pendapat dengan kalimat sederhana dalam kemampuan dengan minat anak. Dengan menggunakan sentra bermain aktif, anak akan terlibat secara aktif baik secara fisik maupun mental karena akan mendapatkan berbagai pengalaman belajar dengan melihat, mendengar dan mengerjakan secara langsung atau praktek dan juga dengan model pembelajaran sentra, diharapkan anak akan mampu mengembangkan kecerdasan bahasa ekspresifnya.

a. Setting di halaman sekolah

b. Setting di sentra bermain

c. Pengembangan Bahasa Ekspresif AnakUsia Dini Melalui Model Pembelajaran Sentra

Berdasarkan dari hasil observasi yang telah dilakukan, peneliti melakukan klarifikasi ulang terhadap justifikasi di atas. Klasifikasi ulang memperlihatkan terdapat peningkatan persentase jumlah indikator berkomunikasi dengan teman sebaya atau orang dewasa.

b) Menunjukkan perilaku senang membaca buku terhadap buku-buku yang dikenali.

c) Mengungkapkan perasaan, ide dengan pilihan kata yang sesuai ketika berkomunikasi.

d) Menceritakan kembali isi cerita secara sederhana.

Dari 10 anak yang diamati pada kelompok B4 terdapat 5 anak yang memliki kecenderungan perkembangan bahasa ekspresif yang menarik untuk diamati. Mereka adalah Dk, Uj, Sp, Rq dan Fa.

Indikator pengembangan bahasa ekspresif yang menjadi fokus perhatian berkembang secara perlahan dengan berjalannya waktu. Tabel berikut memperlihatkan pengembangan bahasa ekspresif anak dalam tahapan obesrvasi minggu pertama dan minggu kedua. yang makin tampak diperlihatkan anak. 
Tabel 4.1 Pengembangan Bahasa Ekspresif dengan menggunakan model pembelajara sentra selama observasi

\begin{tabular}{|c|c|c|c|c|}
\hline \multirow{3}{*}{$\begin{array}{l}\text { Observasi } \\
\end{array}$} & \multicolumn{4}{|c|}{ Pengembangan Bahasa Ekspresif pada Anak Usia Dini } \\
\hline & \multirow{2}{*}{$\begin{array}{l}\text { Mengungkapkan } \\
\text { keinginan, } \\
\text { perasaan, dan } \\
\text { pendapat dengan } \\
\text { kalimat sederhana } \\
\text { dalam } \\
\text { berkomunikasi } \\
\text { dengan teman } \\
\text { sebaya atau orang } \\
\text { dewasa. }\end{array}$} & \multirow{2}{*}{\begin{tabular}{l}
\multicolumn{3}{l}{ Menunjukkan } \\
perilaku senang \\
membaca buku \\
terhadap buku- \\
buku $\quad$ yang \\
dikenali.
\end{tabular}} & \multirow{2}{*}{\begin{tabular}{lr}
\multicolumn{2}{l}{ Mengungkapk } \\
an perasaan, \\
ide rengan \\
pilihan kata \\
yang sesuai \\
ketika \\
berkomunikasi
\end{tabular}} & \multirow{2}{*}{\begin{tabular}{l}
\multicolumn{2}{l}{ Menceritakan } \\
kembali isi \\
cerita secara \\
sederhana.
\end{tabular}} \\
\hline & & & & \\
\hline Nama Anak & Minggu Pertama & & & \\
\hline $\mathrm{Dk}$ & $\sqrt{ }$ & - & - & $\sqrt{ }$ \\
\hline $\mathrm{Uj}$ & - & - & $\sqrt{ }$ & - \\
\hline $\mathrm{Sp}$ & $\sqrt{ }$ & $\sqrt{ }$ & - & - \\
\hline $\mathrm{Fa}$ & $\sqrt{ }$ & $\sqrt{ }$ & - & $\sqrt{ }$ \\
\hline $\mathrm{Rq}$ & $\sqrt{ }$ & - & $\sqrt{ }$ & $\sqrt{ }$ \\
\hline Nama Anak & Minggu Kedua & & & \\
\hline $\mathrm{Dk}$ & $\sqrt{ }$ & $\sqrt{ }$ & $\sqrt{ }$ & $\sqrt{ }$ \\
\hline $\mathrm{Uj}$ & $\sqrt{ }$ & $\sqrt{ }$ & $\sqrt{ }$ & $\sqrt{ }$ \\
\hline $\mathrm{Sp}$ & $\sqrt{ }$ & $\sqrt{ }$ & $\sqrt{ }$ & $\sqrt{ }$ \\
\hline $\mathrm{Fa}$ & $\sqrt{ }$ & $\sqrt{ }$ & $\sqrt{ }$ & $\sqrt{ }$ \\
\hline $\mathrm{Rq}$ & $\sqrt{ }$ & $\sqrt{ }$ & $\sqrt{ }$ & $\sqrt{ }$ \\
\hline
\end{tabular}

Dari hasil penelitian dan dengan melihat perkembangan anak melalui tabel Mengungkapkan keinginan, perasaan, dan pendapat dengan kalimat sederhana dalam berkomunikasi dengan teman sebaya atau orang dewasa; Menunjukkan perilaku senang membaca buku terhadap buku-buku yang dikenali; Mengungkapkan perasaan, ide dengan pilihan kata yang sesuai ketika berkomunikasi; Menceritakan kembali isi cerita secara sederhana. Terlihat peningkatan di minggu kedua. Sehingga dapat disimpulkan bahwa anak berkembang dengan baik, hal ini tidak lepas dari guru, serta strategi pembelajaran yang mampu merangsang kecerdasan bahasa ekspresif anak untuk berkembang menjadi lebih baik.

2. Faktor yang mempengaruhi pengembangan Bahasa Ekspresif Anak Usia Dini dalam Model Pembelajaran Sentra di TK Negeri 01 Tenggarong

Pengembangan Bahasa Anak Usia Dini Tidak menutup kemungkinan akan ditemukan anak usia dini yang mengalami 
kesulitan dalam berbahasa, tidak mampu memahami bahasa lisan, tidak mampu mengutarakan isi hati dengan kalimat, berbicara tidak jelas, gagap, dan sebagainya. Terkait masalah di atas berikut ini penulis mencoba membahas tentang perkembangan bahasa pada anak usia dini. Sebagaimana kita ketahui bersama bahwa bahasa merupakan alat yang penting untuk berkomunikasi bagi setiap orang. Seorang anak akan mengembangkan kemampuan bergaul (social skill) dengan orang lain. Penguasaan keterampilan bergaul dalam lingkungan social dimulai dengan penguasaan kemampuan berbahasa. Tanpa bahasa seseorang tidak akan dapat berkomunikasi dengan orang lain. Anak dapat mengekspresikan pikirannya menggunakan bahasa, sehingga orang lain dapat menangkap apa yang dipikirkan oleh anak.

Dari hasil wawancara kepada guru, terdapat beberapa faktor yang mempengaruhi pengembangan bahasa ekspresif anak usia dini yaitu sebagai berikut (Zubaidah, 2017):

\section{a. FaktorKesehatan}

Kesehatan merupakan faktor yang sangat mempengaruhi perkembangan bahasa anak, terutama pada usia awal kehidupannya. Apabila anak pada usia dua tahun pertama sering mengalami sakitsakitan maka anak tersebut cenderung akan mengalami keterlambatan atau kesulitan dalam perkembangan bahasa b. Intelegensi.

Perkembangan bahasa anak dapat dilihat dari tingkat intelegensinya, anak yang perkembangan bahasanya cepat, pada umumnya mempunyai intelegensi normal atau di atas normal.

c. Status sosial ekonomi keluarga.

Beberapa studi menunjukkan bahwa anak yang berasal dari keluarga miskin mengalami kelambatan dalam perkembangan bahasanya di banding dengan anak yang berasal dari keluarga yang lebih baik status ekonominya, hal ini mungkin disebabkan oleh perbedaan kecerdasan atau kesempatan belajar (keluarga miskin diduga kurang memperhatikan perkembangan bahasa anaknya), ataukedua-duanya.

d. Jeniskelamin.

Pada tahun pertama tidak ada perbedaan vokalisasi antara wanita dan pria, tetapi pada usia dua tahun anak perempuan menunjukkan perkembangan yang lebih cepat dari anak laki-laki.

e. Hubungan keluarga.

Hubungan yang sehat antara orang tua dengan anak (penuh perhatian dan kasih sayang dari orang tuanya) memfasilitasi perkembangan bahasa anak, dan begitu sebalikya hubungan yang tidak sehat bisa menyebabkan perkembangan bahasa anak cenderung akan mengalami stagnasi atau kelainan, seperti gagap dalam berbicara, tidak jelas dalam mengungkapkan kata-kata, merasa takut untuk mengungkapkan 
pendapat, dan berkata yang kasar atau tidak sopan.

\section{SIMPULAN DAN SARAN}

Sebagaimana hasil penelitian yang telah dilakukan berkaitan dengan penerapan model pembelajaran sentra dalam pengembangan kecerdasan bahasa ekspresif anak usia dini pada kelompok B di TK Negeri 01 Tenggarong dapat ditarik kesimpulan sebagai berikut :

1) Model pembelajaran yang digunakan adalah model pembelajaran sentra. Menurut Guru model pembelajaran Sentra memungkinkan anak untuk melakukan manipulasi terhadap berbagai obyek, terlibat dalam role playing saling bercakap-cakap dengan teman-temannya, bereksplorasi, berinteraksi secara fisik, emosional, sosial dan secara kognitif serta kegiatan variatif yang menarik lainnya.Model pembelajaran sentra sangat berperan dalam mengembangkan kecerdasan bahasa ekspresif anak, karena anak-anak dapat belajar berkomunikasi dengan orang lain berbagai cara. Dan juga dalam pengembangan kecerdasan bahasa ekspresif, anak juga mampu Mengungkapkan perasaan, ide dengan pilihan kata yang sesuai ketika berkomunikasi.

2)Faktor yang mempengaruhi pengembangan bahasa ekspresif anak usia dini antara lain :

a. Faktor Kesehatan b. Intelegensi.

c. Status sosial ekonomi keluarga.

d. Jenis kelamin

d. Hubungan keluarga.

Pengembangan kecerdasan bahasa ekspresif melalui metode pembelajaran sentra pada anak usia dini di TK Negeri 01 Tenggarong dilaksanakan dalam proses pembelajaran dan berjalan dengan baik.

\section{DAFTAR RUJUKAN}

Asmawati, Luluk. 2012. Pengelolaan Kegiatan Pengembangan Anak Usia Dini. Tangerang Selatan: Universitas Terbuka.

Asolihin, "Pijakan (Scaffolding) Pembelajaran Di Sentra". 26 maret $2017 . \quad$ https://paudanakbermainbelajar.blogspot.co.id/20 13/10/pijakan-scaffoldingpembelajaran-di.html

Ayomi, Tutur. "Perkembangan Bahasa Ekspresif Pada Anak Usia 2-4 Tahun".15 maret 2017. http://tamarinlppi.blogspot.co.id/2015/10/perkemb angan-bahasa-anak usia-2-4tahun.html

Arifa, Bella Dina. 2014. Peningkatan Keterampilan Bercerita Ekspresif Anak Usia 5-6 Tahun Dengan Role Playing Di Tk Arum Puspita Triharjo Pandak Bantul.Skripsi-UNY

Madyawati, Lilis. 2016. Strategi Pengembangan Bahasa Pada Anak. Jakarta: Prenadamedia group.

Miles, Matthew B \& A. Michael Huberman. 2009. Analisis Data Kualitatif (buku Sumber tentang metode-metode baru). Jakarta: Universitas Indonesia (UI-Press). 
Mulyani, Novi. 2016. Dasar-dasar Pendidikan Anak Usia Dini. Yogyakarta: Kalimedia.

Paizaluddin \& Ermalinda. 2014. Penelitian Tindakan Kelas. Bandung: Alfabeta,

Palenewen, Evie. 2015. Belajar Sains Melalui Bermain. Samarinda: Mulawarman University PRESS.

Pangastuti, Ratna. 2014. Edutaintment Pendidikan Anak Usia Dini. Yogyakarta: Pustaka Pelajar.

Pudjaningsih, Wiwik. 2013 Metode Pengembangan Bahasa:

Penerapannya Pada Pembelajaran Berbasis Tema Dan Sentra Di Taman Kanak-Kanak.Pena Vol.3 No.2

Sugiarto, Eko. 2015. Menyusun Proposal Penelitian Kualitatif (Skripsi dan tesis). Yogyakarta: Suaka Media.

Sugiono. 2014. Metode Penelitian Pendidikan (Pendekatan Kuantitaif,
Kualitatif, dan $R \& D)$. Bandung: Alfabeta,cv.

Sujarweni, V. Wiratna. 2014. Metodologi Penelitian. Yogyakarta: Pustaka Baru Press

Suyadi \& Dahlia. 2014. Implementasi dan Inovasi Kurikulum PAUD 2013. Bandung: PT. Remaja Rosdakarya.

Yaumi, Muhammad. 2012. Pembelajaran Berbasis Multiple Intelligences. Jakarta: Dian Rakyat.

Yusuf, Syamsu \& Nani M. Sugandhi. 2011. Perkembangan Peserta Didik. Jakarta: PT. RajaGrafindo Persada.

Zubaidah, Enny. " Draft Buku Pengembangan Bahasa Anak Usia Dini”. 17 Juni

2017.https://www.academia.edu/7106982/Pe ngembangan_Bahasa_Anak_Usia_Dini?auto =download 